\title{
THE DIFFERENCES OF THE DURATION OF FAMILY PLANNING PROGRAM REPORT BETWEEN USING GOOGLE SHEETS MEDIA AND MANUAL COUNTING METHOD AT PUSKESMAS SONGGON, SONGGON DISTRICT, BANYUWANGI REGENCY
}

Wildan Anugrah Erlangga ${ }^{1}$, Fitri Nurina Septiana ${ }^{1}$, Emilia Eka Arrianti ${ }^{1}$, Prafidina Qualisa ${ }^{1}$, Lukman Hakim $^{1}$, Estya Nadya Meitavany ${ }^{1}$, Ulinnuha Qurrota A'yunin ${ }^{1}$, Ariikah Dyah Lamara ${ }^{1}$, Niswah Silmi Fatimah $^{1}$, Pandu Satriya Adi ${ }^{1}$, Linda Dewanti*2

${ }^{1}$ Medical Students, Faculty of Medicine, Universitas Airlangga, Indonesia ${ }^{2}$ Department of Public Health-Preventive Medicine, Faculty of Medicine, Universitas Airlangga, Indonesia

ABSTRACT
Based on the results of interviews with the coordinator of the
family planning program at the Puskesmas Songgon, their data
collection system was still written manually in the Kohort book
which must then be classified and processed further to obtain
processed data that describes the situation and conditions of the
family planning program application in Songgon District. The
aims of this research to determine the effectiveness and efficiency
of the family planning program report duration between the use of
Google Sheets media and the manual counting method at the
Puskesmas Songgon. The implementation of the program were 23
May 2019 at Puskesmas Songgon Hall. This program was
designed based on the needs of the field of family planning
management at the Puskesmas Songgon. This program was
created using a computer, the Google Sheets application, which is
an application that resembles Microsoft Excel, but is managed by
Google and accessed via a browser. It creates two types of
formats, namely forms for data entry and automatic calculation
reports. The results of this study, it can be seen that the program
used by group 2 is 10 times more efficient in calculating the
achievements of the family planning program.

\section{ARTICLE HISTORY}

Received: June 21, 2020

Revised: July 18, 2020

Accepted: August 1, 2020

Published: August 30, 2020

(Online)

doi:

10.20473/jcmphr.v1i2.21700

\section{KEYWORDS \\ Family Planning Report, Google Sheet}

\section{CORRESPONDING \\ AUTHOR}

Linda Dewanti

$₫$ lindaperisdiono@yahoo.com Department of Public HealthPreventive Medicine, Faculty of Medicine, Universitas Airlangga, Jl. Mayjen. Prof. Dr. Moestopo $47 \quad$ Surabaya, Indonesia

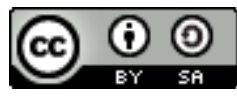

\section{INTRODUCTION}

Health development is an important aspect of health development, aimed at increasing awareness, willingness, and ability to live a healthy life for everyone in order to realize an optimal degree of public health. Puskesmas as the first level health facility has an important role in improving healthy sub-districts for the realization of a healthy Indonesia. Puskesmas are at the forefront of implementing basic health efforts. In order to carry out its functions optimally, it is necessary to have a good health center organization management which includes service performance, service processes, and the resources used. This is done to improve quality, risk management, and patient safety at the health center and provide safe and quality health services for the community.

Based on the regulation of the Minister of Health of the Republic of Indonesia Number 44 of 2016 concerning Puskesmas Management guidelines, it is said that the Puskesmas (public health care) as the organizer of basic health services for the 
community in its working area plays a role in organizing health efforts to increase awareness, willingness and ability to live healthy for each population in order to obtain a healthy degree of health. optimal.

Family planning according to WHO (World Health Organization) is an action that helps individuals or married couples to (1) avoid unwanted births, (2) get the desired birth, (3) adjust the interval between births, (4) control the timing at birth in relation to the age of husband and wife, (5) determining the number of children in the family.

Based on the 2011 Health Survey, the percentage of Puskesmas with complete resource intake for the national family planning program was only $32.2 \%$. Most of the Puskesmas (97.5\%) have implemented family planning service activities, have health workers who provide family planning services as much as $98.3 \%$, have $58 \%$ trained family planning health personnel, have guidelines still 58\%, and implement evaluation guidance by districts/cities already $71.2 \%$. Referring to this data, it appears that there are several activities that still need to be improved, such as the number of trained health personnel, the availability of guidelines and strengthening of family planning-related evaluation guidance, including data management and information on family planning programs.

Based on the results of interviews with the coordinator of the family planning program at the Songgon Health Center, their data collection system is still written manually in the Kohort book which must then be classified and processed further in order to obtain processed data that describes the situation and conditions of the family planning program application in Songgon District. However, because the data obtained is too much and processing is still using the manual counting method, data presentation cannot be in accordance with the predetermined time so that the preparation of follow-up plans and evaluations is hampered.

\section{MATERIALS AND METHODS}

Create two types of formats, namely forms for data entry and automatic calculation reports. We have adjusted the two types of formats to the data required by the Puskesmas for reporting to the District and Provincial Health Offices. We made two kinds of forms, namely the family planning service form, and the family planning kohort register. The family planning service form (Figure 2) is used by midwives during family planning services. Each family planning service form file contains a monthly form that is divided into 9 villages, each village is divided by the government and the private sector.

Data were entered based on the patient's residence and the location of family planning services. At the end of the family planning service form file, there is an automatic counting report sheet (Figure

3). The family planning kohort register (Figure 4) is a substitute for the family planning kohort register book that was previously written manually. This register was initiated by filling in all childbearing age each village.

Data on the results of monthly family planning services will be entered automatically in the family planning kohort according to the family planning kohort register system in the form of columns A, 
$\mathrm{B}$, and $\mathrm{C}$. There is also an automatic calculation column for Puskesmas PKP reporting with calculations according to the operational definition of the Health Office regarding Essential SMEs in the service sector of family planning

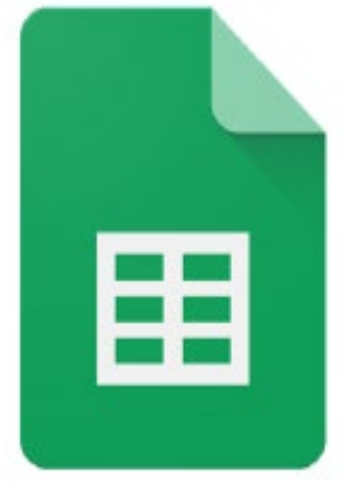

\section{Google Sheets}

Figure 1. Google Sheets ${ }^{\mathrm{TM}}$ Logo

The files are arranged in such a way into several folders for easy access for the midwives at the Puskesmas and for the regional midwives. The availability of this file can be accessed at any time because the server comes from Google.

The introduction and training of this program done after all the preparations for Google Sheets have been completed. We provide introduction and training to all midwives at the Puskesmas and regional midwives who work under the Songgon Community Health Center. After that, we made comparisons between the group using the manual method and the group using the program we created. Each individual in each group worked on 5 patient data which were input using a computer.

The time and location for the implementation of the introduction and training program are 23 May 2019 at the Songgon Health Center Hall. The targets in this program are all midwives, both in the main health center and in the area around the Songgon Health Center.

The data were collected by using the observation method from the time of receiving the sample Kohort questions, inputting data from the Kohort questions, categorizing the data into available forms, calculating the data, and compiling the final data recapitulation as the final report. Measurement data uses a stopwatch instrument to measure duration, as well as notepaper and writing instruments to record time.

The duration of the compilation of family planning program reports using the manual counting method The time taken from the time the midwife starts receiving sample questions from the kohort until the recapitulation of the family planning report data is formed, stopwatch and stationery. 


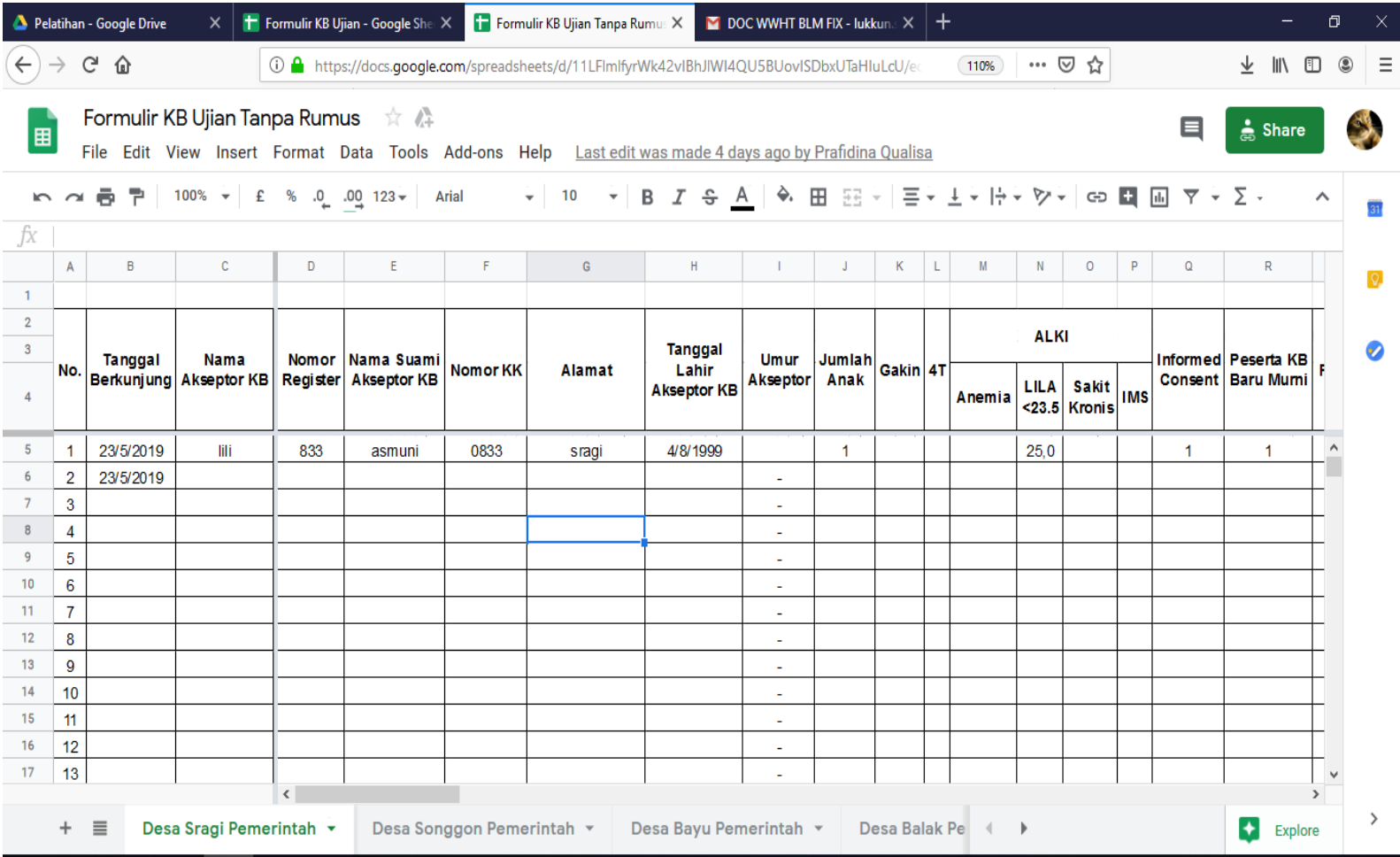

* 0 草

Figure 2. Display of the Table Family Planning Service Form

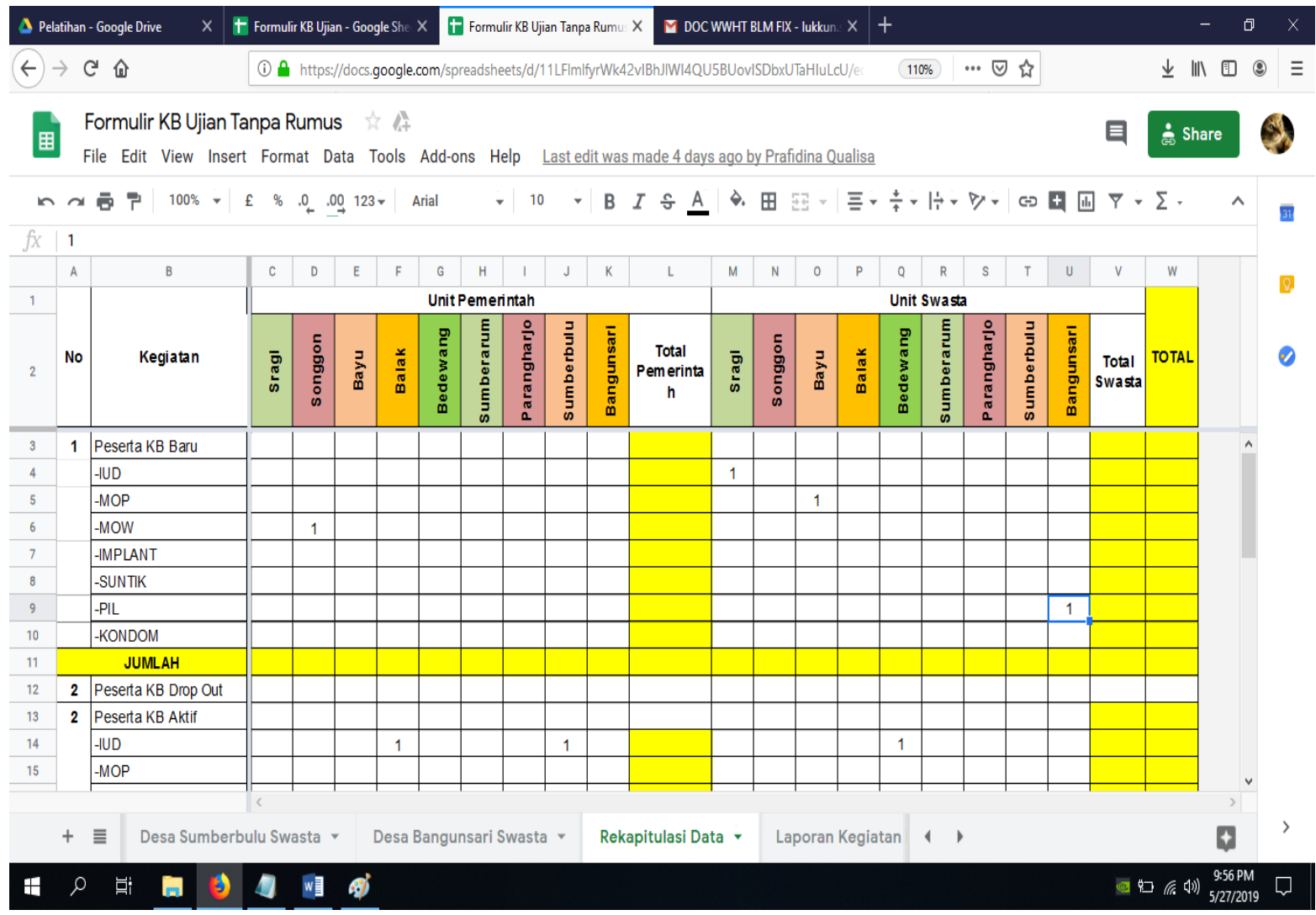

Figure 3. Display of Data Recapitulation Results for PKP 


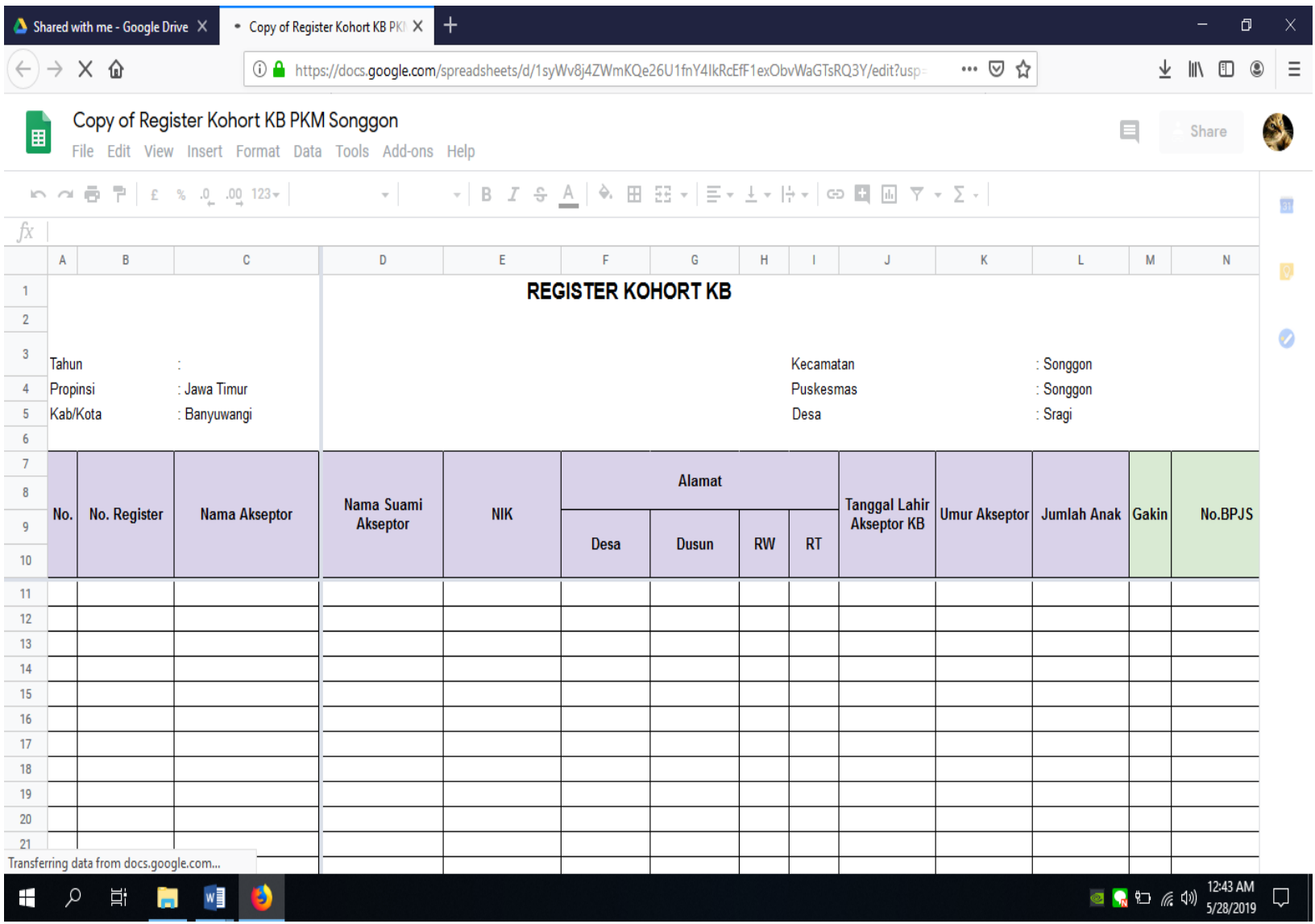

Figure 4. Display of the Family Planning Kohort Register

\section{RESULT}

Table 1. Data on the duration of the Family Planning program report processing time using Google Sheets compared to the manual counting system

\begin{tabular}{|c|c|c|c|}
\hline Number & Sample & Duration & Results \\
\hline \multirow{6}{*}{1} & \multirow{6}{*}{$\begin{array}{c}\text { The group that is } \\
\text { working with } \\
\text { manual }\end{array}$} & N1: 50 Minutes & N1 : Successfull, incomplete \\
\hline & & N2 $: 53$ Minutes & N2 : Successfull, incomplete \\
\hline & & N3 : 55 Minutes & N3 : Successfull, incomplete \\
\hline & & N4 : 56 Minutes & N4: Successfull, incomplete \\
\hline & & N5 : 57 Minutes & N5 : Successfull, incomplete \\
\hline & & N6 : 60 Minutes & N6 : Successfull, incomplete \\
\hline \multirow{6}{*}{2} & & N1 : 20 Minutes & N1 : Successfull, Complete \\
\hline & & N2 $: 23$ Minutes & N2: Successfull, Complete \\
\hline & The group that use & N3 : 25 Minutes & N3 : Successfull, Complete \\
\hline & Google Sheet program & N4 : 26 Minutes & N4 : Successfull, Complete \\
\hline & & N5 : 28 Minutes & N5 : Successfull, Complete \\
\hline & & N6 : 29 Minutes & N6: Successfull, Complete \\
\hline
\end{tabular}

\section{DISCUSSION}

The Songgon Contraception Report program powered by Google Sheets aims to directly increase the effectiveness and efficiency of processing family planning service reports and family planning kohort registers. This program uses Google Sheets online software as the main tool. The advantages offered by this program, among others, are tasks that can be done by many people at the same time, eliminating 
calculation time (because it is done automatically using a formula), and can be done independently without having to gather in one place. This program is free of charge, can be accessed anytime and anywhere and can be developed according to the needs of the Puskesmas. ${ }^{6-8}$

The average duration for family planning reports by group 2 was 26 minutes, while the duration for family planning reports by group 1 was 56 minutes. Group 2 successfully completed $(100 \%)$ all of the recapitulation counts totaling 146 calculations (26 minutes). Group 1 only managed to complete $14(9.6 \%)$ of the 146 calculations that had to be done (56 minutes). Group 2 succeeded in working on the data processing process using Google sheets as much as $100 \%$ of the sample questions given, while group 1 was only successful in calculating $9.6 \%$ of the calculations from the sample questions given in the same time frame.

Based on the above results, group 2 can do $100 \%$ data entry and complete calculations in only 26 minutes, while group 1 can only do $9.6 \%$ compared to the results done by group 2, From here it can be seen that the program used by groups 2 are 10 times more efficient in calculating the achievements of the family planning program.

Based on the 2011 Health Survey, the percentage of Puskesmas with complete resource intake for the national family planning program was only $32.2 \%$. Most of the Puskesmas $(97.5 \%)$ have implemented family planning service activities, have health workers who provide family planning services as much as $98.3 \%$, have $58 \%$ trained family planning health personnel, have guidelines still $58 \%$, and implement evaluation guidance by districts/cities already $71.2 \%$. Referring to this data, it appears that there are several activities that still need to be improved, such as the number of trained health personnel, the availability of guidelines and strengthening of evaluation guidance related to family planning, including data management and information on family planning programs. According to Law of the Republic of Indonesia Number 36 of 2009 concerning Health Article 78, the Government is responsible for and guarantees the availability of personnel, service facilities, equipment, and medicines in providing family planning services that are safe, quality, and affordable to the public. In line with this in the Law of the Republic of Indonesia Number 52 of 2009, article 1 concerning Population Development and Family Development states that family planning is an effort to regulate the birth of a child, the distance and ideal age of childbirth, regulate pregnancy, through promotion, protection and assistance in accordance with rights. Reproductive rights to create a quality family, ${ }^{5,9,10}$

In order to strengthen and achieve the objectives of family planning services, support for family planning service management is very important, starting from planning, implementation, monitoring, and evaluation. One of the challenges in family planning services is that the availability, affordability, and quality of family planning services are not yet optimal. However, good service management is expected to increase availability, accessibility, acceptability, and quality of service. ${ }^{11}$ 
Health Information System is a set of structures that includes data, information, indicators, procedures, tools, technology, and human resources that are interrelated and managed in an integrated manner to direct actions or decisions that are useful in supporting healthy development. Health Information is Health Data that has been processed or processed into a form that contains value and meaning which is useful for increasing knowledge in supporting healthy development.

There are several factors that affect the duration of data processing regarding the achievements of the family planning program at the Puskesmas, including factors for cadres and regional midwives who work at Posyandu, factors for the main Puskesmas midwife and the coordinator for family planning programs at the main health center, as well as facilities for facilities. The factors of cadres and regional midwives who work in Posyandu include: (1) The limited ability of Human Resources in the knowledge of technology and information; (2) There is no training to increase knowledge of technology and information, as well as the use of applications that can be used. For the main health center midwife and family planning program coordinator, among others are (1) Limited human resource capacity in the knowledge of technology and information; (2) There is no training to increase knowledge of technology and information, as well as the use of applications that can be used. Meanwhile, the factors affecting the facilities and infrastructure are: (1) Existing equipment (software and hardware) has not been used optimally; (2) Internet connection is still slow; (3) The required application was not found. This resulted in: 1) The collected data on the achievement of the family planning program was not optimal; 2) The data processing model is still manual; 3) Delay in the data processing. These three things cause the follow-up plan and evaluation to be hampered. ${ }^{4,6}$

The family planning policy (family planning) aims to control population growth through efforts to reduce birth rates. This family planning policy together with other development efforts will further improve family welfare. Efforts to reduce birth rates are carried out by inviting childbearing age to have family planning. Meanwhile, residents who have not yet entered the childbearing age are given an understanding and understanding of family planning. To support and accelerate the achievement of development goals in the field of family planning, several policies have been established, namely expanding coverage, coaching family planning participants to continuously use contraceptives, institutionalizing, and cultivating NKKBS and increasing the integration of family planning implementation. Furthermore, to support the implementation of these policies, operational efforts will continue to be strengthened in the form of an equal distribution of family planning services, improving the quality of both personnel and family planning service facilities, raising independence, increasing the participation of the younger generation, and strengthening program implementation in the field. ${ }^{11-13}$

Family planning program management in the information systems section applies an up to date information system with clear 
outcomes. Each province achieves the target of the family planning program to be further advocated and facilitated to the district/city. Data and information along with the results of their management that have been obtained are then coordinated with active working networks and partners, including OPD (Regional Government Organizations) in each Regency / City that has been formed in accordance with Government Regulation No. 47 of 2007. In the process of data and information management related to the family planning program, the problems that have caused the collection of data and information to be obstructed so that the management is not optimal, resulting in an incomplete followup plan and evaluation are: (1) The limited ability of Human Resources in technological knowledge and information; (2) Existing equipment (software and hardware) has not been used optimally; (3) the application system built has not been able to provide solutions in data processing at the district/city level; (4) Limited budget support, especially in the development and fostering of application systems. ${ }^{11-12}$

For this reason, a solution is needed to improve the data processing of family planning program achievements so that follow-up plans and follow-up evaluations can be planned. The program was designed based on the needs of the Songgon Community Health Center's Family Planning management field, namely with an application made using a computer, the Google Sheets application, which is an application that resembles Microsoft Excel, but is managed by Google and accessed via a browser (web browser).

\section{CONCLUSION}

Puskesmas Songgon needs innovative methods to optimize data collection and processing of family planning achievements and socialization to cadres of each village, regional midwives, and independent midwives for the use of applications that have been made. Adopting a system for reporting the achievements of the family planning program with the Google sheet system in all Puskesmas units, and in all program units that require an integrated reporting system.

\section{REFERENCES}

1. Ministry of Health, Republic of Indonesia. 2008. Tentang Mutu Pelayanan Kesehatan di Puskesmas. Jakarta: Ministry of Health, Republic of Indonesia.

2. Ministry of Health, Republic of Indonesia. 2014. Keputusan Menteri Kesehatan no. 75 Tahun 2014 tentang Pusat Kesehatan Masyarakat. Jakarta: Ministry of Health, Republic of Indonesia

3. Ministry of Health, Republic of Indonesia. 2014. Peraturan Menteri Kesehatan Republik Indonesia Nomor 44 Tahun 2016 Tentang Pedoman Manajemen Puskesmas. Jakarta, Ministry of Health, Republic of Indonesia

4. Puskesmas Songgon. 2018. PKP Songgon Puskesmas 2018. Banyuwangi: Puskesmas Songgon.

5. Ministry of Health, Republic of Indonesia. 2012. Laporan Nasional Riset Fasilitas Kesehatan 2011, Jakarta, Badan Litbang Kesehatan.

6. Mulyono S. 2004. Operations Research. Jakarta: Faculty of Economics, University of Indonesia.

7. Ministry of Health, Republic of Indonesia. 2013. Pedoman Pelayanan 
Keluarga Berencana di Fasilitas

Pelayanan Kesehatan. Jakarta,

Ministry of Health, Republic of Indonesia.

8. Badan Kependudukan dan Keluarga Berencana Nasional. 2008. Instrumen Kajian Mandiri Instrumen Mengukur Kinerja Fasilitas, USAID, Badan Pusat Statistik.

9. Undang-undang Republik Indonesia Nomor 36 tahun 2009 tentang Kesehatan.

10. Undang-undang Republik Indonesia Nomor 52 tahun 2009, pasal 1 tentang Perkembangan Kependudukan dan Pembangunan Keluarga.

11. BKKBN, 2014. Draft Pedoman Penyelenggaraan Pelayanan KB dalam Jaminan Kesehatan Nasional, Jakarta, Badan Koordinasi Keluarga Berencana Nasional.

12. Ministry of Health, Republic of Indonesia. 2012. Pedoman Sistem Pencatatan dan Pelaporan Pelayanan Keluarga Berencana, Jakarta, Ministry of Health, Republic of Indonesia.

13. Ministry of Health, Republic of Indonesia. 2007. Analisis Situasi dan Bimbingan Teknis Pengelolaan Pelayanan KB, Jakarta, Ministry of Health, Republic of Indonesia. 